\title{
Environmental Literacy of Islamic Boarding School Students: Study in MA Bilingual-Sidoarjo, East Java, Indonesia
}

\author{
${ }^{1 *}$ H. Husamah, ${ }^{1}$ Fuad Jaya Miharja, ${ }^{1}$ Dewi Arif Hidayati \\ Department of Biology Education, Faculty of Teacher Training and Education, \\ Universitas Muhammadiyah Malang, Jl. Raya Tlogomas No. 246, Malang, East Java, 65144, \\ Indonesia. \\ *Corresponding Author e-mail: usya_bio@umm.ac.id
}

Received: June 2020; Revised: June 2020; Published: June 2020

\begin{abstract}
Environmental literacy is an important aspect that must be instilled in education, especially in Islamic educational institutions, one of which is an Islamic boarding school (IBS). This study aimed to analyze the EL of students (focus on ecological knowledge/EK, verbal commitment/VC, and actual commitment/AC) in Madrasah Aliyah (MA) Bilingual-Sidoarjo. The approach used was a quantitative, supported by qualitative data. This ex-post facto study was conducted for six months. The research subjects were 120 students ( 40 each grade), taken by purposive sampling. EL was assessed using MSELS/I. The analysis is done by input the score of each participant's answer into the table, calculated the relative frequency of each indicator to facilitate the meaning of the data, then analyzing the answers. The scores are tabulated using Microsoft Excel 2010. The results showed that the EL scores of students varied, from sufficient to high levels. Students in class XI and XII-IPA have relatively high EK scores, while students in class X-IPS have low scores. The distribution of EK scores in one class group is also very diverse. Students tend to have the attitude (VK) to agree to take pro-environment actions, especially on small things, but vice versa in matters related to the system and the involvement of many people. At the level of behavior (AC), students tend to show pro-environmental actions. Thus it can be concluded that EL students tend to be diverse and improve their quality according to grade level.
\end{abstract}

Keywords: Environmental literacy, Islamic boarding school, MA bilingual

How to Cite: Husamah, H., Miharja, F., J., \& Hidayati, D., A. (2020). Environmental Literacy of Islamic Boarding School Students: Study in MA Bilingual-Sidoarjo, East Java, Indonesia. Prisma Sains: Jurnal Pengkajian Ilmu dan Pembelajaran Matematika dan IPA IKIP Mataram, 8(1), 57-68. doi:https://doi.org/10.33394/j-ps.v8i1.2766

https://doi.org/10.33394/j-ps.v8i1.2766

Copyright $\odot$ 2020, Husamah et al This is an open-access article under the CC-BY License.

\section{INTRODUCTION}

The Government and Indonesian people have made many efforts to implement environmental education to shape the pro-environmental generation (Nurwidodo et al., 2019, 2020; Susilastri \& Rustaman, 2015). According to various researchers, environmental problems have been identified as one of the most critical problems faced today (Hudson, 2001; Pereira, 2015). Environmental problems are generally described as industrialization, overpopulation, the impact of the development of science and technology, increasing demand, and globalization flows (Davis, 1998; Jianping et al., 2014; Abdullah Karataş, 2016; Sherbinin et al., 2009).

Environmental education material (EE), in general, has been included in the curriculum in schools, in almost all countries (Afandi, 2013; Hudson, 2001; Sawitri, 2016). In Indonesia, EE has become local content in schools or integrated environmental problems in the subject matter (Adisendjaja \& Romlah, 2008; Muhaimin, 2015; Steele et al., 2015; Sudjoko, 2014). These efforts are innovations carried out in order to improve students' competence and environmental knowledge (literacy) for the better. However, studies on increasing environmental competencies need to be encouraged (Farwati et al., 2017). 
Environmental literacy (EL) needs to be owned by everyone (Hollweg et al., 2012). Therefore overall integration in the soul needs to be developed and studied (Genlott \& Grönlund, 2013; Kidman \& Casinader, 2019; Liang et al., 2018; O’Brien, 2007). Besides, in a more specific, the contribution of Islam in the development of EL also needs to be encouraged. Islam contains very pro-environmental values (Farida et al., 2017; Hudha et al., 2019; Husamah \& Setiawan, 2016; Mohamed, 2012, 2014; Musthofa et al., 2017; Rahman et al., 2019; Rahmawati et al., 2018; Sukarsono, 2018a, 2018b; Sukarsono \& Utami, 2019).

However, sometimes improper educational patterns cause EL based on Islamic values not to appear or even be ignored (Blumstein \& Saylan, 2007; Darling-Hammond et al., 2019; Erdoğan et al., 2009; Stevenson et al., 2013), including Islamic educational institutions (Ashraf, 2019; Mohamed, 2012), commonly known as Islamic boarding schools, Islamic Boarding Schools (IBS), and " madrasa " (Nadrati et al., 2019; Nofiaturrahmah, 2017; Sumarni \& Susanna, 2014; Susiyani \& Subiyantoro, 2017; Tanshzil, 2012). In this case, for example, we can see in the case of Iran, where the EL component of action not much attention and even neglect in the curriculum (Karimzadegan \& Meiboudia, 2012). In connection with that, it needs to be analyzed how the EL conditions in pesantren, which in this case we focus on schools in Indonesia, namely MA Bilingual-Sidoarjo.

Some researchers, both on a national and international scale have focused on the theme of EL at the high school and college levels. The data presented has been published in various international journals, accredited national journals, proceedings, and directories. Many researchs has been conducted to measure and analyze EL in high school students (Nasution, 2016; Wardani et al., 2019). Other studies have shown students' EL profiles to be quite diverse. EL students of natural schools and Adiwiyata regular schools have only reached the low level (Susilastri \& Rustaman, 2015; R. Wulandari, 2017), medium (Rinaldy, 2018), and high on school adiwiyata and non-adiwiyata (Elvazia, 2017).

Several researchers are tried to develop high school biology learning tools based on local potential, environmental literacy, and conservation attitudes (Kahar \& Fadhilah, 2018), application of teaching materials (Kahar, 2018), learning based on environmental pollution modules (Fitriana et al., 2018), analysis of problem-solving based learning models (Mauludah et al., 2018), the application of technological and community science approaches (Widowati, 2011), and environmental learning through the development of specific subjects based on problem-based learning pedagogy (Widianingsih et al., 2017) to improve the attitude of caring for the environment or environmental literacy of high school students. According to Prasetiyo (2017), much-interrupted learning is not fully supported by optimizing students' EL.

The development of EL evaluation instruments tested on prospective teachers (Anom et al., 2018), and gap analysis of EL achievement indicators in the junior high school curriculum (Anggraini et al., 2018) has also been done. Other research in the form of EL mapping in junior high school students (Nurwaqidah et al., 2019; Pujianti et al., 2018), EL improvement at the elementary school level (Febriasari \& Supriatna, 2017; Istikomayanti et al., 2016; Narut \& Nardi, 2016; D. E. Wulandari, 2018), and in higher education especially for prospective teachers (Farwati et al., 2017). Some other articles in the form of a review of the importance of student awareness of the environment (Perkasa et al., 2017), the importance of EL education as a supporter of tourism villages (Kurniasih et al., 2015), as well as the importance of local culture to be integrated into learning to create contextual learning so can encourage EL middle school students (Ilhami, 2019).

Some research that has been obtained related to the relationship between schools, environmental literacy, and Islamic values leads to Islamic knowledge and values that are believed to influence students' thinking patterns and perceptions about environmental literacy (Rahmawati et al., 2018), Moreover, in literacy development research through internalization of Islamic values and monotheism in project-based learning and environmental conservation (Farida et al., 2017; Rahman et al., 2019). The importance of revitalizing ecological ethics is 
also an essential part of the development of environmental awareness (Mohamed, 2012, 2014; Sukarsono, 2018a, 2018b; Sukarsono \& Utami, 2019).

In this regard, this study aims to analyze students' EL (focus on ecological knowledge, verbal commitment, and actual commitment) in the Bilingual MA-Sidoarjo. The urgency and contribution of this research is the availability of scientific data related to EL students in the Bilingual MA Sidoarjo-Indonesia as a material for a recommendation of environmental study activities and as a basis for implementing collaborative activities among stakeholders. Moreover, as a foundation for schools to develop pro-environment activities and strengthening students' EL.

\section{METHOD}

\section{Research Type}

This research was a quantitative descriptive study supported by qualitative data.

\section{Research Location and Time}

The study was conducted at MA Bilingual Sidoarjo, which is located at JL. Junwangi No. 43B, Junwangi, Krian, Sidoarjo, East Java, Indonesia. This school was a modern school/pesantren that has a soft skills and character building based santri development system. The research was conducted from December 2019 to May 2020 (six months).

\section{Population, Sampling Techniques and Subjects}

The population used in this study were 1032 students. As much as 120 students were selected as subjects (40 students per class level). The sampling technique uses non-probability techniques through random sampling.

\section{Research procedure}

The research procedures included school observation, review of instrument (MSELS) questionnaire and translate the questionnaire into Indonesian. Research activities carried out in several steps, as follows: (1) condition students who are research samples, (2) distribute environmental literacy questionnaires to the research sample with 80 minutes completion time, (3) Pay attention to the environmental literacy questionnaire that has been done by the research sample, (4) data analysis, and (5) described the students' EL.

\section{Method of collecting data}

The data collecting used non-test techniques through questionnaires. The questionnaire used to obtain data on knowledge, attitudes, and behavior towards the student's environmental literacy. The questionnaire is adapted from Middle Schools Environmental Literacy Survey/ Instrument (MSELS/I) based on National Environmental Literacy Assessment (NELA) program organized by the National Oceanic and Atmospheric Administration (NOAA) which consists of ecological knowledge, verbal commitment, environmental sensitivity, environmental feelings, issue identification, issue analysis, action planning, and actual commitment (McBeth et al., 2011). The analysis in this study focused on aspects of ecological knowledge, verbal commitment, and actual commitment. McBeth (2011) said that MSELS has tested both construct validity and reliability, and has become a standard reference assessment or evaluation for EL tests in several countries.

\section{Data analysis technique}

Data analysis was performed with descriptive statistics and presented in numbers making it easier to interpret. This analysis is done by entering the participant's answer score into the table and calculated to make it easier to interpret. Scores are tabulated into Microsoft Excel 2010. 


\section{RESULTS AND DISCUSSION}

Researchers have analyzed the students' EL who focused on aspects of ecological knowledge, verbal commitment, and actual commitment. Classification of students' environmental knowledge shows scores that vary from moderately to high (Figure 1). Students in class XI-IPA and XII-IPA have relatively high knowledge scores, respectively $64.05(\sigma=$ 12.78) dan $59.04(\sigma=17.98)$. Meanwhile, the students of class X-IPS have a relatively low score, which is $49.91(\sigma=15.7)$. The distribution of students' environmental knowledge scores in one class group is very diverse, indicated by the high standard deviation (Figure 2). The results also showed a tendency to increase students' environmental knowledge. This assumption is based on increasing common knowledge at each grade level, from class $\mathrm{X}$ to class XII.

Furthermore, a students' cognitive change is not an indicator that can be seen in a short time, but instead shows a process of assimilation and adaptation of new value with existing knowledge (Hendrowati, 2015; Mulyani et al., 2012; Puntambekar, 2006; Romli, 2015). It represents a long process of changing the students' cognitive level (Adhitama et al., 2014; Lestari, 2011).

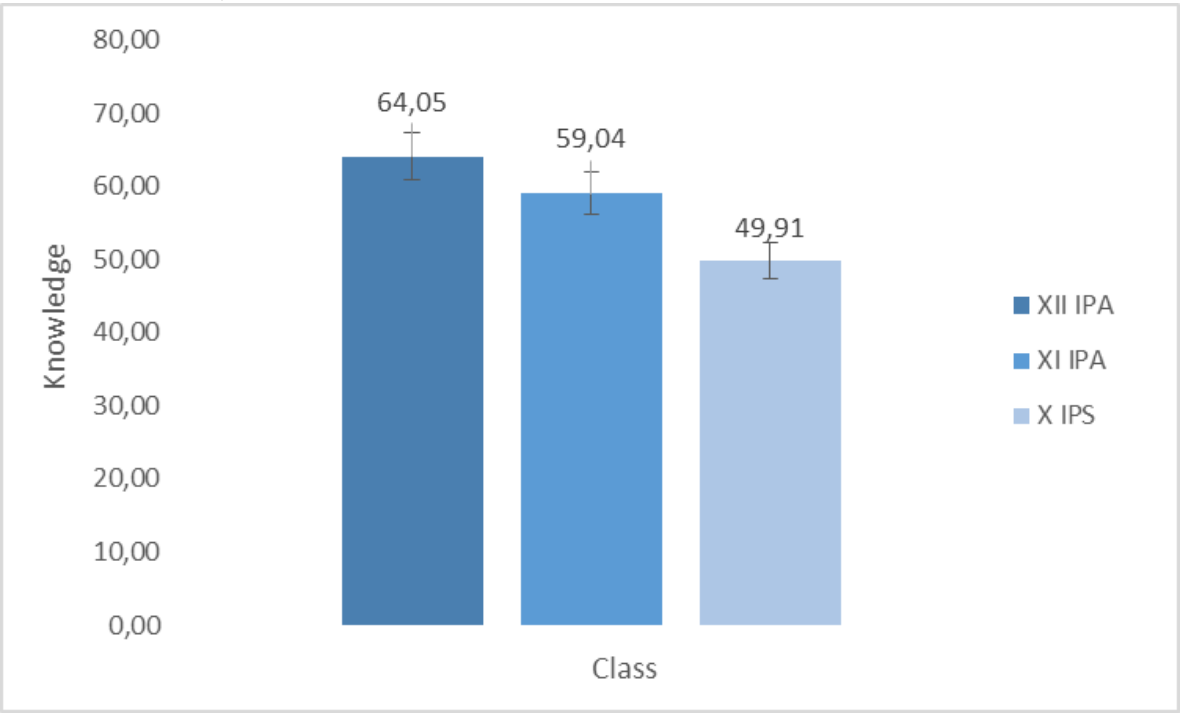

Figure 1. The average of students' environmental knowledge

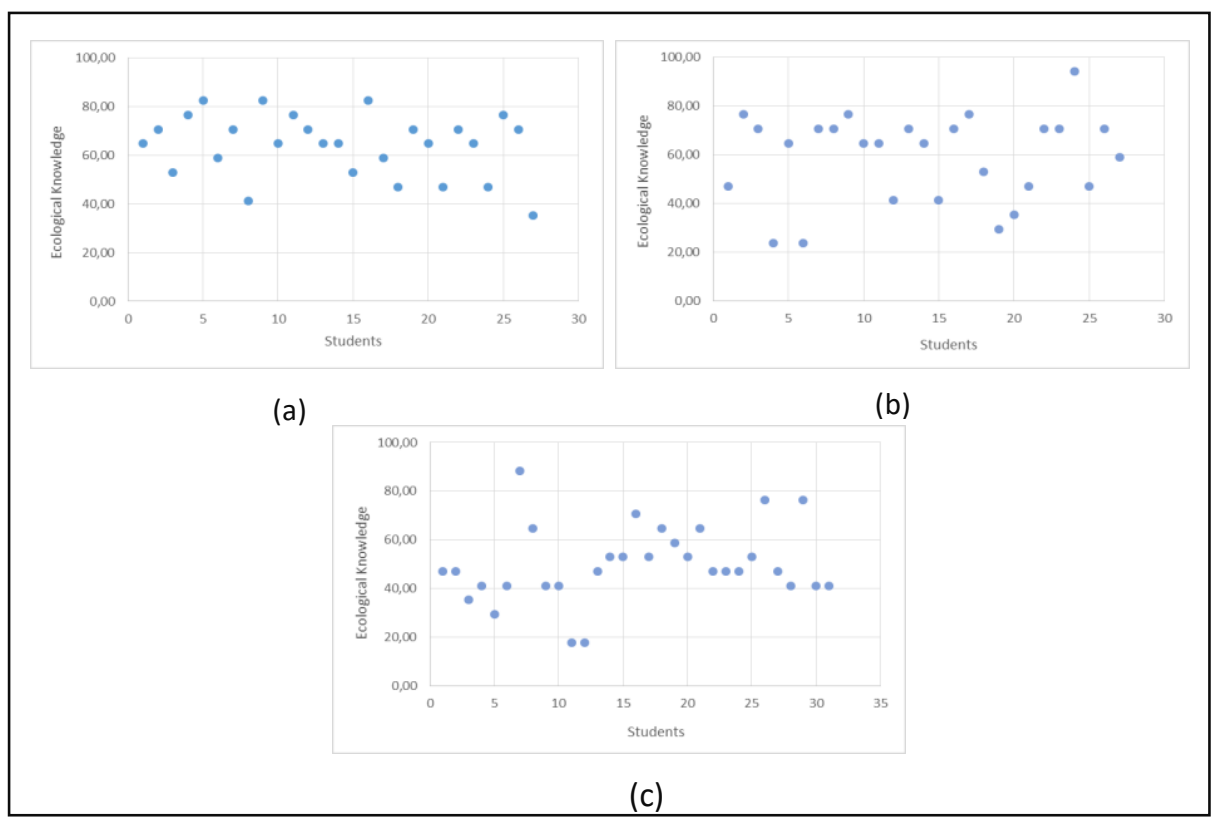

Figure 2. The distribution of students' environmental knowledge of class XII-IPA (a), XI-IPA (b), and X IPS (c) 
Many studies have reported the strong correlations between levels of knowledge and attitudes and behavior, especially on how to manage and treat the environment (Ardan, 2016; Saltan \& Divarci, 2017; Spinola, 2015). However, what needs to be underlined is the change in attitude and behavior is a complex and multidimensional process (Ojedokun \& Balogun, 2010; Yu \& Yu, 2017). A combination of several factors such as learning patterns (El-Batri et al., 2019; Igbokwe, 2012), the period of the learning process (Aguado \& Holl, 2018), integration of character-based values in schools (Judiani, 2010; Miharja et al., 2020), sociocognitive conflict management (Desfandi et al., 2017), and assimilation of Islamic values become essential dimensions that will determine how students' attitudes towards the environment (Farida et al., 2017; Hudha et al., 2019; Mohamed, 2012; Rahman et al., 2019).

Figure 3 shows how students' attitudes toward environmental issues. Some exciting things that can be assessed based on the results of this study are students tend to agree (score 4) to carry out pro-environmental actions, especially on small things that can be done daily independently such as saving water, using energy-saving lamps, walking, and delivery of information and pollution reduction campaigns. Conversely, some things related to the system and the involvement of many people, students tend to show the opposite attitude (score 1), such as not consuming products made from animals, the use of air conditioners, and sorting waste. These are in line with Rachmani (2015), that someone tends to agree on pro-environmental actions, especially on small things that can be done every day.

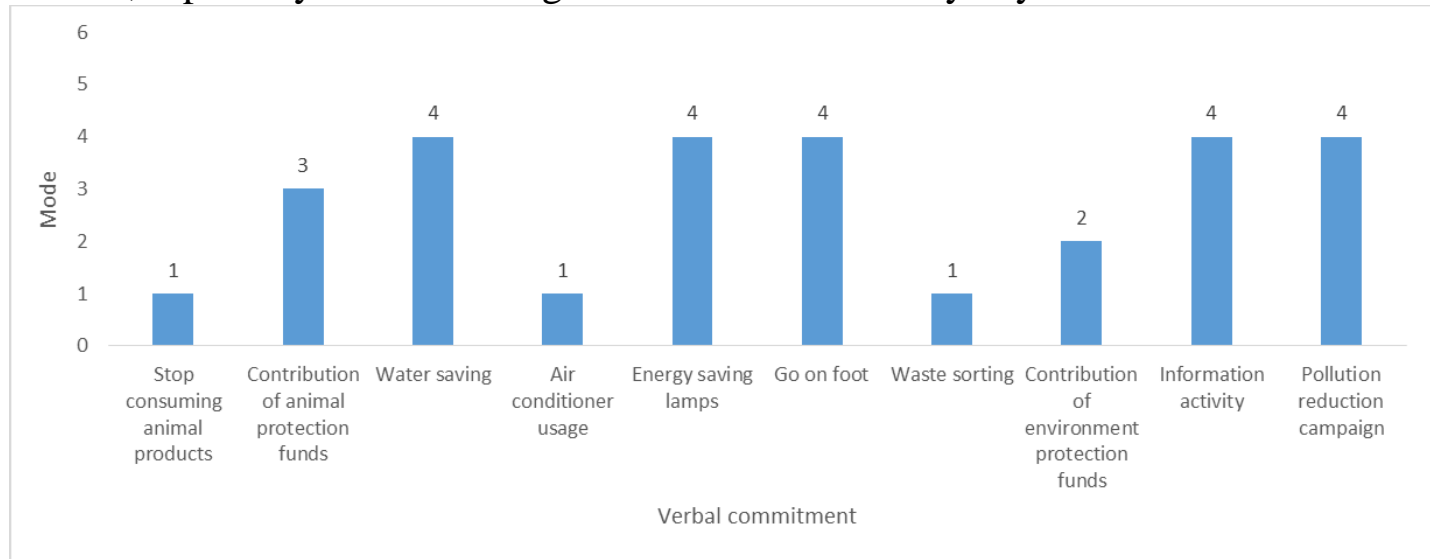

Figure 3. Trend of students' attitudes towards the environment

In the case of waste segregation, this activity involves many people and a well-planned and well-organized waste management system. In reality, some steps for sorting waste are not followed by appropriate management steps. The rubbish that has been sorted at the first level is often in vain because the waste management officer re-mixes the rubbish. Some underlying factors include limited facilities and infrastructure for waste management and or different levels of knowledge.

Meanwhile, the use of air conditioning habits is relatively difficult to change. This behavior tends to raise the potential for conflict due to differences in interests that demand priority (Higgins et al., 2005). Even in developed countries, government interference makes the use of air conditioning decrease. In Japan, for example, according to Kurz, Gardner, Verplanken, and Abraham (2015), the government finally issued the Cool Biz initiative, which was designed in partnership with the fashion industry, targeting a drastic reduction in the use of air conditioning in offices.

At the level of behavior (actual commitment), it turns out that students tend to show the existence of pro-environmental steps, as shown in Figure 4. However, the results of this study also indicate that there are parts that need to be improved to apply pro-environment actions, notably efforts to prevent pollution. 


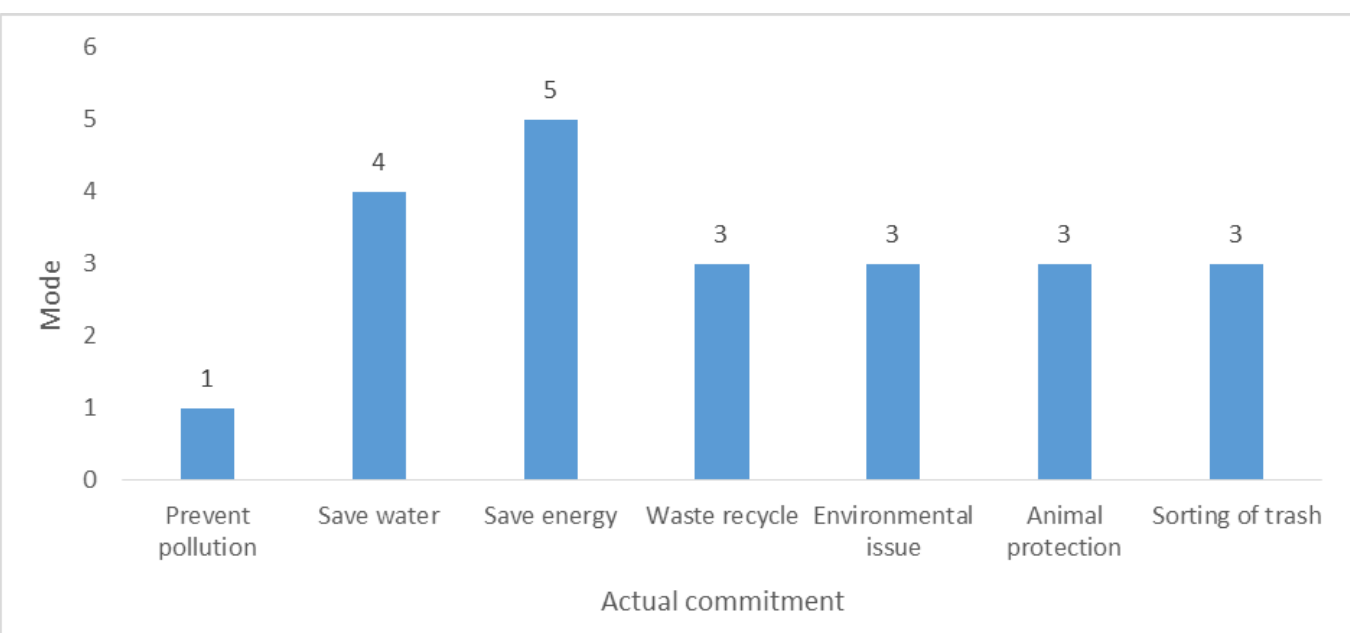

Figure 4. Trends in students' behavior towards the environment

According to Teksoz (2011), teaching students about pollution will build the skills and attitudes needed to strengthen the way of thinking, values held, and decisions made in the context of sustainable development. Efforts to raise awareness about the need for sustainability of environmental functions need to involve problems and solutions. Furthermore, according to Daniel, Stanisstreet, and Boyes (2004) efforts to explore student ideas about the extent to which their actions can impact pollution are significant. Students must realize that they play a significant role in reducing pollution. That awareness is both individual and collective. Therefore, according to Karataş and Karataş (2016), at the practical level, the implementation of environmental education in schools aims to provide an understanding of pollution and to protect the environment. Thus, the parties involved in environmental education will later play a role in understanding individuals and groups related to the information.

Figure 4 shows that students are accustomed to doing energy-saving and water-saving actions. On the other hand, the behavior of recycling products, literacy activities, animal protection, and efforts to sort waste is quite often done (score 3). In this regard, Prestin and Pearce (2010) recommend increasing student knowledge about environmentally friendly behavior, for example, about what recycling and what cannot be recycled, is essential, and the future orientation of the environment. At a more appropriate level, Coyle (2005) asserts that asserts that "It needs to insist that students receive an adequate base of environmental knowledge, and it needs to more comprehensively deploy its well-developed strategies, curricula, and texts, large numbers of learning facilities, natural acres, field experts, and nonformal institutions in this effort".

\section{CONCLUSION}

The results showed EL scores (ecological knowledge, verbal commitment, and actual commitment) varied and tended to increase in quality according to grade level. Aspects of students' ecological knowledge vary, from sufficient to high levels. Students in class XI and XII IPA have relatively high knowledge scores, while students of class X IPS have low scores. The distribution of the value of students' environmental knowledge in one class group is very diverse. The distribution of the value of students' environmental knowledge in one class group is very diverse. There is a tendency for students to increase their environmental knowledge, based on increasing general knowledge at each grade level. Some exciting things that can be learned are the tendency of students to approve pro-environment actions, especially on small things that can be done every day independently. Conversely, some things related to the system and the involvement of many people, students tend to show the opposite attitude. At the level of behavior (actual commitment), students tend to show the existence of pro-environmental steps, although there are things that need to be improved to implement pro-environment actions, especially efforts to prevent pollution. 


\section{RECOMMENDATION}

The limitation of this study is that the types of classes that are allowed to be assessed are different, namely X IPS, XI IPA, and XII IPA, so they cannot see the difference in EL between class types. Therefore, the next researcher needs to look at the difference in EL between X IPS with X IPA, between XI IPS with XI IPA, and XII IPS with XII IPA so that the results are more comprehensive. In addition, aspects that have minor values need attention in the form of efforts to improve these aspects, for example how to strengthen "prevent pollution", "stop consuming animal products", "minimize air conditioner usage", and "waste sorting".

\section{ACKNOWLEDGMENT}

This research was funded by the Universitas Muhammadiyah Malang through the Internal Research Program-Scheme of the Featured Programs Study Centers/Institutions, Academic year 2019/2020 with the Letter of Assignment number: E.2.a/238/BAA$\mathrm{UMM} / \mathrm{III} / 2020$. Therefore, our thanks go to the Rector, Vice Rector for Academic Affairs, Director of the Directorate of Research and Community Service, and Head of the Center for Environmental and Population Studies at the Universitas Muhammadiyah Malang who have supported and approved the implementation of this research. We would also like to thank the Head of the MA Bilingual Sidoarjo-East Java for giving permission for data collection and observation.

\section{REFERENCES}

Adhitama, R. S., Kusnadi, K., \& Supriatno, B. (2014). Kesadaran metakognitif siswa dalam pembelajaran berbasis proyek pada pokok bahasan pencemaran lingkungan. ASIMILASI, $I(1), \quad 2-11 . \quad$ https://text-id.123dok.com/document/q0god7xz-student-s-metacognitiveawareness-through-projectbased-learning-in-the-concept-of-polution-adhitamaassimilation-jurnal-pendidikan-biologi-19622-1-sm.html

Adisendjaja, Y. H., \& Romlah, O. (2008). Pembelajaran pendidikan lingkungan hidup: Belajar dari pengalaman dan belajar dari alam. In e-Journal. ainpekalongan.

Afandi, R. (2013). Integrasi pendidikan lingkungan hidup melalui pembelajaran ips di sekolah dasar sebagai alternatif menciptakan sekolah hijau. Jurnal Pedagogia, 2(1), 98-108.

Aguado, E., \& Holl, A. (2018). Differences of corporate environmental responsibility in small and medium enterprises: Spain and Norway. Sustainability, 10(6), 1877. https://doi.org/10.3390/su10061877

Anggraini, W., Karyanto, P., \& Sarwanto, S. (2018). Education for sustainable development (EfSD): Gap of indicators for environmental literacy achievement in the middle school curriculum. EDUSAINS, 10(2), 301-308.

Anom, K. W., Sukaryawan, M., \& Haryani, M. E. (2018). Pengembangan dan validasi instrumen evaluasi literasi lingkungan. Jurnal Penelitian Pendidikan Kimia: Kajian Hasil Penelitian Pendidikan Kimia, 5(1), 38-44.

Ardan, A. S. (2016). The development of biology teaching material based on the local wisdom of Timorese to improve students knowledge and attitude of environment in caring the preservation of environment. International Journal of Higher Education, 5(3), 190-200. https://doi.org/10.5430/ijhe.v5n3p190

Ashraf, M. A. (2019). Exploring the potential of religious literacy in Pakistani education. Religions, 10(7), 1-15. https://doi.org/10.3390/rel10070429

Blumstein, D. T., \& Saylan, C. (2007). The failure of environmental education [And how we can fix it]. PLoS Biology, 5(5), 73-76. https://doi.org/10.1371/journal.pbio.0050120

Coyle, K. (2005). Environmental literacy in America: What ten years of NEETF/roper research and related studies say about environmental literacy in the U.S. The National Environmental Education \& Training Foundation.

Daniel, B., Stanisstreet, M., \& Boyes, E. (2004). How can we best reduce global warming? School students' ideas and misconceptions. International Journal of Environmental Studies, 61(2), 211-222. https://doi.org/10.1080/0020723032000087907 
Darling-Hammond, L., Flook, L., Cook-Harvey, C., Barron, B., \& Osher, D. (2019). Implications for educational practice of the science of learning and development. Applied Developmental Science, O(0), 1-44. https://doi.org/10.1080/10888691.2018.1537791

Davis, J. (1998). Young children, environmental education, and the future. Early Childhood Education Journal, 26(2), 117-123. https://doi.org/10.1023/A:1022911631454

Desfandi, M., Maryani, E., \& Disman. (2017). Building ecoliteracy through Adiwiyata program (Study at Adiwiyata School in Banda Aceh). Indonesian Journal of Geography, 49(1), 51-56. https://doi.org/10.22146/ijg.11230

El-Batri, B., Alami, A., Zaki, M., \& Nafidi, Y. (2019). Extracurricular environmental activities in Moroccan middle schools: Opportunities and challenges to promoting effective environmental education. European Journal of Educational Research, 8(4), 1013-1028. https://doi.org/10.12973/eu-jer.8.4.1013

Elvazia, H. A. (2017). Perbandingan literasi lingkungan dan sikap peduli lingkungan siswa sekolah adiwiyata dengan siswa sekolah non adiwiyata di Kabupaten Pringsewu (Studi Perbandingan pada siswa kelas X di Pringsewu Tahun Pelajaran 2016/2017). FKIP Universitas Lampung.

Erdoğan, M., Kostova, Z., \& Marcinkowski, T. (2009). Components of environmental literacy in elementary science education curriculum in Bulgaria and Turkey. Eurasia Journal of Mathematics, Science and Technology Education, 5(1), 15-26. https://doi.org/10.12973/ejmste/75253

Farida, I., Hadiansah, Mahmud, \& Munandar, A. (2017). Project-based teaching and learning design for internalization of environmental literacy with islamic values. Jurnal Pendidikan IPA Indonesia, 6(2), 277-284. https://doi.org/10.15294/jpii.v6i2.9452

Farwati, R., Permanasari, A., Friman, H., \& Suhery, T. (2017). Potret literasi lingkungan mahasiswa calon guru kimia di Universitas Sriwijaya. Journal of Science Education And Practice, 1(1), 1-8. https://doi.org/10.33751/jsep.v1i1.376

Febriasari, L. K., \& Supriatna, N. (2017). Enhance environmental literacy through problem based learning. Journal of Physics: Conference Series, 895(1). https://doi.org/10.1088/1742-6596/895/1/012163

Fitriana, A. N., Roshayanti, F., \& Rakhmawati, R. (2018). Pengaruh modul pencemaran lingkungan untuk meningkatkan kemampuan literasi lingkungan siswa di SMA Negeri 10 Semarang. Seminar Nasional Sains Dan Entrepreneuship V, 71-74.

Genlott, A. A., \& Grönlund, $\AA$. (2013). Improving literacy skills through learning reading by writing: The iWTR method presented and tested. Computers and Education, 67(2013), 98-104. https://doi.org/10.1016/j.compedu.2013.03.007

Hendrowati, T. Y. (2015). Pembentukan pengetahuan lingkaran melalui pembelajaran asimilasi dan akomodasi teori konstruktivism Piaget. Jurnal E-DuMath, 1(1), 1-16. https://doi.org/10.26638/je.78.2064

Higgins, S., Hall, E., Wall, K., Woolner, P., \& Mccaughey, C. (2005). The impact of school environments: A literature review. In Communication.

Hollweg, K. S., Taylor, J., Bybee, R. W., Marcinkowski, T. J., McBeth, W. C., \& Zoido, P. (2012). Developing a framework for assessing environmental literacy: Executive summary (No. 1033934).

Hudha, A. M., Husamah, H., \& Rahardjanto, A. (2019). Etika lingkungan: Teori dan praktik pembelajarannya. UMM Press.

Hudson, S. J. (2001). Challenges for environmental education: Issues and ideas for the 21st century. BioScience, 51(4), 283. https://doi.org/10.1641/00063568(2001)051[0283:cfeeia]2.0.co;2

Husamah, H., \& Setiawan, A. (Eds.). (2016). Pemahaman lingkungan secara holistik. UMM Press \& PSLK UMM.

Igbokwe, A. B. (2012). Environmental literacy assessment: Exploring the potential for the assessment of environmental education/programs in Ontario Schools. International 
Journal for Cross-Disciplinary Subjects in Education, 3(1), 648-656. https://doi.org/10.20533/ijcdse.2042.6364.2012.0091

Ilhami, A. (2019). Kontribusi budaya lokal terhadap literasi lingkungan: Studi kasus di SMP Pandam Gadang Sumatera Barat. JNSI: Journal of Natural Science and Integration, 2(2), 1. https://doi.org/10.24014/jnsi.v2i2.7788

Istikomayanti, Y., Suwono, H., \& Irawati, M. H. (2016). Pembelajaran eksperiensial group investigation (GI) sebagai upaya mengembangkan kemampuan literasi lingkungan siswa kelas IV MI. JPBI (Jurnal Pendidikan Biologi Indonesia), 2(1), 57-71. https://doi.org/10.22219/JPBI.V2I1.3372.G3961

Jianping, L., Minrong, L., Jinnan, W., Jianjian, L., Hongwen, S., \& Maoxing, H. (2014). Global environmental issues and human wellbeing. In L. Jianping, L. Minrong, W. Jinnan, L. Jianjian, S. Hongwen, \& H. Maoxing (Eds.), Report on Global Environmental Competitiveness (2013) (urrent Chi, pp. 3-21). Springer Berlin Heidelberg. https://doi.org/10.1007/978-3-642-54678-5_1

Judiani, S. (2010). Implementasi penguatan pendidikan karakter di sekolah melalui penguatan kurikulum. Jurnal Pendidikan Dan Kebudayaan, 15(3), 280-289. https://doi.org/10.1111/j.1469-8986.1974.tb00542.x

Kahar, A. P. (2018). Application of mangrove ecosystem material based on local potential to improve student's enviromental awareness attitude. Didaktika Biologi: Jurnal Penelitian Pendidikan Biologi, 2(1), 1-8.

Kahar, A. P., \& Fadhilah, R. (2018). Pengembangan perangkat pembelajaran biologi SMA berbasis potensi lokal, literasi lingkungan dan sikap konservasi. Pedagogi Hayati, 2(2), 16-24. https://doi.org/10.31629/PEDAG. HAYATI.V2I2.832

Karataş, A, \& Karataş, E. (2016). Environmental education as a solution tool for the prevention of water pollution. Journal of Survey in Fisheries Sciences, 3(1), 61-70. https://doi.org/10.18331/SFS2016.3.1.6

Karataş, Abdullah. (2016). Environmental impacts of globalization and a solution proposal. Environmental Impacts of Globalization and a Solution Proposal, 6(2), 64-70.

Karimzadegan, H., \& Meiboudia, H. (2012). Exploration of environmental literacy in science education curriculum in primary schools in Iran. Procedia - Social and Behavioral Sciences, 46, 404-409. https://doi.org/10.1016/j.sbspro.2012.05.131

Kidman, G., \& Casinader, N. (2019). Developing teachers' environmental literacy through inquiry-based practices. Eurasia Journal of Mathematics, Science and Technology Education, 15(6). https://doi.org/10.29333/ejmste/103065

Kurniasih, N., Komariah, N., \& Rachmawati, T. S. Rodiah, S. (2015). Pendidikan literasi lingkungan sebagai penunjang desa wisata Agro Kecamatan Padaherang Kabupaten Pangandaran. Jurnal Aplikasi Ipteks Untuk Masyarakat, 4(1), 18-21.

Kurz, T., Gardner, B., Verplanken, B., \& Abraham, C. (2015). Habitual behaviors or patterns of practice? Explaining and changing repetitive climate-relevant actions. Wiley Interdisciplinary Reviews: Climate Change, 6(1), 113-128. https://doi.org/10.1002/wcc.327

Lestari, N. N. S. (2011). Pengaruh model pembelajaran berbasis masalah (problem-based learning) dan motivasi belajar terhadap prestasi belajar fisika bagi siswa kelas VII SMP. Journal Teknologi Pembelajaran Indonesia, 1(1), 1-21. http://oldpasca.undiksha.ac.id/ejournal/index.php/jurnal_tp/article/view/297/91

Liang, S. W., Fang, W. T., Yeh, S. C., Liu, S. Y., Tsai, H. M., Chou, J. Y., \& Ng, E. (2018). A nationwide survey evaluating the environmental literacy of undergraduate students in Taiwan. Sustainability (Switzerland), 10(6), 1-21. https://doi.org/10.3390/su10061730

Mauludah, N., Roshayanti, F., \& Sumarno, S. (2018). Pengaruh model pembelajaran berbasis pemecahan masalah untuk meningkatkan kemampuan literasi lingkungan siswa di SMA Negeri 1 BATANGAN. Jurnal Biologi Dan Pembelajarannya, 5(2), 15-20.

McBeth, B., Hungerford, H., Marcinkowski, T., Volk, T., Cifranick, K., Howell, J., \& Meyers, 
R. (2011). National environmental literacy assessment, phase two: measuring the effectiveness of North American environmental education programs with respect to the parameters of environmental literacy. Final report. In NOAA and NAAEE. Accessed November (Vol. 28).

Miharja, F. J., Kusumawardana, A. S., \& Setiawan, A. (2020). Evaluasi program penguatan karakter: Studi di sekolah non- piloting PPK di Kota Malang. JUPIIS: Jurnal Pendidikan Ilmu-Ilmu Sosial, 12(1), 7-22. https://doi.org/10.24114/jupiis.v12i1.14476.g13171

Mohamed, N. (2012). Revitalising an eco-justice ethic of Islam by way of environmental education: Implications for Islamic education (Issue March). Stellenbosch University.

Mohamed, N. (2014). Islamic education, eco-ethics and community. Studies in Philosophy and Education, 33(3), 315-328. https://doi.org/10.1007/s11217-013-9387-y

Muhaimin, M. (2015). Implementasi model pembelajaran berbasis masalah lokal dalam mengembangkan kompetensi ekologis pada pembelajaran IPS. SOSIO DIDAKTIKA: Social Science Education Journal, 2(1), 12-21. https://doi.org/10.15408/sd.v2i1.1409

Mulyani, A., Kamid, K., \& Muhamad, D. (2012). Proses konstruksi pengetahuan siswa bertipe belajar visual pada pelajaran Biologi. Edu-Sains, 1(2). https://doi.org/10.22437/jmpmipa.v2i1.1348

Musthofa, Z. A., Husamah, H., Hudha, A. M., Muttaqin, T., Hasanah, I., \& Setyawan, D. (2017). Mengurai sengkarut bencana lingkungan (Refleksi jurnalisme lingkungan \& deep ecology di Indonesia). UMM Press \& PSLK UMM.

Nadrati, B., Wijayanto, W. P., \& Musniati, M. (2019). Gambaran perilaku hidup bersih dan sehat (PHBS) santri di Pondok Pesantren Ad Diinul Qoyyim Lombok Barat. Holistik Jurnal Kesehatan, 13(1), 1-6. https://doi.org/10.33024/hjk.v13i1.1126

Narut, Y. F., \& Nardi, M. (2016). Analisis sikap peduli lingkungan pada siswa kelas VI sekolah dasar di Kota Ruteng. Scholaria: Jurnal Pendidikan Dan Kebudayaan, 9(3), 259-266.

Nasution, Q. (2016). Analisis kemampuan literasi lingkungan siswa SMA Kelas X di Samboja dalam pembelajaran biologi. Proceeding Biology Education Conference, 352-358.

Nofiaturrahmah, F. (2017). Metode pendidikan karakter di Pesantren. Jurnal Pendidikan Agama Islam, 11(2), 201-216. https://doi.org/10.14421/jpai.2014.112-04

Nurwaqidah, S., Suciati, S., \& Ramli, M. (2019). Environmental literacy mapping based on adiwiyata and non adiwiyata at junior high school in Ponorogo. The First International Conference on Education, Science and Training: Empowering Educational Human Resources for Global Competitiveness, 3(15), 179-190. https://doi.org/10.18502/kss.v3i15.4365

Nurwidodo, N., Al Muhdar, M. H. I., Rohman, F., Iriani, D., Herlina, H., \& Fausan, M. M. (2019). Building pro-environmental behavior among school community of Adiwiyata green school. Jurnal Pendidikan Biologi Indonesia, 5(1), 23-32. https://doi.org/10.22219/jpbi.v5i1.7233

Nurwidodo, N., Amin, M., Ibrohim, I., \& Sueb, S. (2020). The role of eco-school program (Adiwiyata) towards environmental literacy of high school students. European Journal of Educational Research, 9(3), 1089-1103. https://doi.org/10.12973/eu-jer.9.3.1089

O'Brien, S. R. M. (Iowa S. U. (2007). Indications of environmental literacy: using a new survey instrument to measure awareness, knowledge, and attitudes of university-aged students. In Retrospective Theses and Dissertations.

Ojedokun, A. O., \& Balogun, S. (2010). Environmental attitude as a mediator of the relationship between self-concept, environmental self-efficacy and responsible environmental behaviour among residents of high density areas in Ibadan Metropolis, Nigeria. Ethiopian Journal of Environmental Studies and Management, 3(2), 111-119. https://doi.org/10.4314/ejesm.v3i2.59834

Pereira, J. C. (2015). Environmental issues and international relations, a new global disorder. Journal of Ecosystem \& Ecography, 58(1), 191-209. https://doi.org/10.1590/00347329201500110 
Perkasa, M., Agrippina, A., \& Wiraningtyas, W. (2017). Sustainable chemistry oriented on chemistry learning to increase student awareness to the environment. Jurnal Sainsmat, 6(2), 63-72.

Prasetiyo, P. (2017). Pembelajaran matapelajaran biologi materi lingkungan di sekolah mengengah atas dan daya dukungnya terhadap literasi lingkungan siswa. Florea Jurnal Biologi Dan Pembelajarannya, 4(2), 55-58. https://doi.org/10.25273/florea.v4i2.1857

Prestin, A., \& Pearce, K. E. (2010). We care a lot: Formative research for a social marketing campaign to promote school-based recycling. Resources, Conservation and Recycling, 54(11), 1017-1026. https://doi.org/10.1016/j.resconrec.2010.02.009

Pujianti, N., Munandar, A., \& Surakusumah, W. (2018). Environmental literacy in agriculture and coastal areas. Journal of Physics: Conference Series, 1013(1). https://doi.org/10.1088/1742-6596/1013/1/012007

Puntambekar, S. (2006). Analyzing collaborative interactions: divergence, shared understanding and construction of knowledge. Computers and Education, 47(3), 332351. https://doi.org/10.1016/j.compedu.2004.10.012

Rachmani, N. (2015). Analisis semiotika iklan Ades versi "Langkah Kecil Memberikan Perubahan" dalam menyingkap pesan tersembunyi tentang kepedulian lingkungan hidup. EJournal Ilmu Komunikasi, 3(2), 432-446. http://ejournal.ilkom.fisipunmul.ac.id/site/wp-content/uploads/2015/06/ejurnal rani ok (06-29-15-05-47-56).pdf

Rahman, N. A., Zabidi, F. N. M., Othman, M. Y., Halim, L., Iksan, Z., \& Abdullah, W. N. W. (2019). Conceptual framework for integration of Tauhidic Elements for Environmental Conservation (TEfEC): A review. International Journal of Academic Research in Business and Social Sciences, 8(3), 58-72. https://doi.org/10.6007/IJARPED/v8-i3/6265

Rahmawati, A., Supardi, K. I., ES, S. M., \& Haryani, S. (2018). Environment-based education integrated Islamic values to cultivate environmental literacy and attitudes. Advances in Social Science, Education and Humanities Research (ASSEHR), 247(Iset), 70-74. https://doi.org/10.2991/iset-18.2018.15

Rinaldy, R. (2018). Perbandingan literasi lingkungan dan sikap peduli lingkungan antara siswa kelas XI MIPA sekolah adiwiyata dengan non adiwiyata di kota Bandar Lampung [FKIP Universitas Lampung]. https://doi.org/10.1017/CBO9781107415324.004

Romli, K. (2015). Akulturasi dan asimilasi dalam konteks interasi antar etnik. Ijtimaiyya, 8(1). http://ejournal.radenintan.ac.id/index.php/ijtimaiyya/article/viewFile/859/738

Saltan, F., \& Divarci, O. F. (2017). Using blogs to improve elementary school students' environmental literacy in science class. European Journal of Educational Research, 6(3), 347-355. https://doi.org/10.12973/eu-jer.6.3.347

Sawitri, D. R. (2016). Early childhood environmental education in tropical and coastal areas: A meta-analysis. IOP Conf. Series: Earth and Environmental Science, 55, 012050. https://doi.org/10.1088/1755-1315/55/1/012050

Sherbinin, A. De, Carr, D., Cassels, S., \& Jiang, L. (2009). Population and enviornment. Annual Review of Enviornmental Resources, 32, 345-373. https://doi.org/10.1146/annurev.energy.32.041306.100243.Population

Spinola, H. (2015). Environmental literacy comparison between students taught in Eco-schools and ordinary schools in the Madeira Island region of Portugal. Science Education International, 26(3), 392-413. https://files.eric.ed.gov/fulltext/EJ1074869.pdf

Steele, R., Darmapatni, I., Zandvliet, D., Matakupan, S., Wijayanto, H., Djulia, E., Asyar, R., Yusuf, M., \& Kamil, D. (2015). Review implementasi pendidikan lingkungan di Provinsi Jambi. Seminar Nasional XII Biologi, Sains, Lingkungan, Dan Pembelajarannya, 40-60.

Stevenson, K. T., Peterson, M. N., Bondell, H. D., Mertig, A. G., \& Moore, S. E. (2013). Environmental, institutional, and demographic predictors of environmental literacy among middle school children. PLoS ONE, 8(3). https://doi.org/10.1371/journal.pone.0059519

Sudjoko, S. (2014). Perkembangan dan konsep dasar pendidikan Lingkungan Hidup. In S. 
Sudjoko, S. Mariyam, S. A. Wijaya, W. Setianingsih, \& S. Hidayati (Eds.), Pendidikan lingkungan hidup (pp. 1-41). Universitas Terbuka.

Sukarsono, S. (2018a). The importance of the religious and scientific values-based knowledge in the conservation of the natural resources and environment in Indonesia. International Journal of Applied Environmental Sciences, 13(8), 755-766.

Sukarsono, S. (2018b). Islamic values in the practice of natural conservation in Indonesia. Advances in Social Science, Education and Humanities Research, 231(Amca), 624-627. https://doi.org/10.2991/amca-18.2018.173

Sukarsono, S., \& Utami, U. (2019). Knowledge system of religious communities in watershed conservation education; Case studies in Islamic Boarding Schools in East Java and West Nusa Tenggara, Indonesia. IOP Conference Series: Earth and Environmental Science, 314(1), 012057. https://doi.org/10.1088/1755-1315/314/1/012057

Sumarni, I., \& Susanna, D. (2014). Kondisi kesehatan lingkungan pesantren dan perilaku hidup bersih dan sehat siswa dengan kejadian hepatitis. Kesmas: National Public Health Journal, 9(2), 179-186. https://doi.org/10.21109/kesmas.v9i2.515

Susilastri, S. D., \& Rustaman, N. Y. (2015). Students' environmental literacy profile in schoolbased nature and in school that implement the Adiwiyata program. Seminar Nasional Konservasi Dan Pemanfaatan Sumber Daya Alam, 263-269.

Susiyani, A. S., \& Subiyantoro, S. (2017). Manajemen boarding school dan relevansinya dengan tujuan pendidikan Islam di Muhammadiyah Boarding School (MBS) Yogyakarta. Jurnal Pendidikan Madrasah, 2(2), 327. https://doi.org/10.14421/jpm.2017.22-08

Tanshzil, S. W. (2012). Model pembinaan pendidikan karakter pada lingkungan pondok pesantren dalam membangun kemandirian dan disiplin santri. Jurnal Penelitian Pendidikan, 13(2), 1-18.

Teksoz, G. T. (2011). Managing air pollution: How does education help? In M. Khallaf (Ed.), The Impact of Air Pollution on Health, Economy, Environment and Agricultural Sources (Vol. 1, pp. 397-422). IntechOpen. https://doi.org/10.1016/j.colsurfa.2011.12.014

Wardani, R. A. K., Karyanto, P., \& Ramli, M. (2019). Analysis of high school students' environmental literacy. Journal of Physics: Conference Series, 1022(1), 012057. https://doi.org/10.1088/1742-6596/1022/1/012057

Widianingsih, W. M., Karyanto, P., Prayitno, B. A., \& Irawati, M. (2017). Environmental learning through development of subject specific pedagogy based on problem based learning to reinforce student's environmental literacy in grade X MIA senior high school. Proceeding Biology Education Conference, 14, 441-448.

Widowati, A. (2011). Membentuk generasi berliterasi lingkungan dengan penerapan pendekatan STM dalam pembelajaran sains. Seminar Nasional Pendidikan IP, 40174414.

Wulandari, D. E. (2018). Peran literasi lingkungan dalam menumbuhkan kepedulian lingkungan (studi kasus siswa kelas atas di MI Ma'arif Purwantoro Wonogiri). Fakultas Tarbiyah dan Ilmu Keguruan-UIN Ponorogo.

Wulandari, R. (2017). Perbedaan environmental literacy siswa SMA adiwiyata dan nonadiwiyata pada pengelolaan sampah dan penghijauan. Fakultas Sains dan Teknologi, UIN Sunan Kalijaga.

Yu, T.-Y., \& Yu, T.-K. (2017). The moderating effects of students' personality traits on proenvironmental behavioral intentions in response to climate change. International Journal of Environmental Research and Public Health, 14(12), 1472. https://doi.org/10.3390/ijerph14121472 